\title{
Protein CBFA2T1
}

National Cancer Institute

\section{Source}

National Cancer Institute. Protein CBFA2T1. NCI Thesaurus. Code C18320.

Protein CBFA2T 1 (604 aa, $68 \mathrm{kDa}$ ) is encoded by the human RUNX1T1 gene. This protein plays a role in the regulation of gene transcription. 